\title{
Modelling of natural water retention in the catchment basin of the Opava river during flood
}

\author{
M. Palát Sr..$^{*}$, M. Palát Jr. ${ }^{1}$, J. Prudký ${ }^{2}$ \\ ${ }^{1}$ Faculty of regional development and international studies, Mendel University in Brno, Zemédèlská 1, 61300 \\ Brno, Czech Republic, ${ }^{*}$ e-mail:palat@mendelu.cz \\ ${ }^{2}$ Faculty of Agronomy, Mendel University in Brno, Zemédèlská 1, 61300 Brno, Czech Republic
}

Abstract: Palát M. Sr., Palát M. Jr., J. Prudký J. 2013: Modelling of natural water retention in the catchment basin of the Opava river during flood. - Beskydy, 6 (2): 109-116

The aim of the analysis involved in the article is to define the significance of separate factors affecting the natural process of retention in the catchment basin thus can assess the priorities in undertaking flood protection. The analysis was based on results achieved by using a new method how to determine water retention in the catchment basin. Resulting dependent variables of effective long-time retention, effective short-time retention, effective total retention and maximum specific runoff for single catchment basins of the Opava river, were evaluated statistically by means of linear regression and correlation analysis, stepwise regression and multiple regression. It is possible to say, that the results achieved may suggest to reevaluate some established views concerning the role of separate factors influencing natural retention of the landscape. The results of the research testify the fact that in case of densely settled floodplain regions the combined flood protection measures, i.e. as technical and nature friendly ones should be applied. Due to relatively small collection of observations it is not possible to generalize all the conclusions absolutely, nevertheless they have a certain validity at least for the given area.

Keywords: catchment basin, natural water retention, effective short-time and long-time retention, effective total retention, maximum specific runoff, stepwise regression, multiple regression

\section{Introduction}

Water belongs to the most important and, at the same time, also to the most widespread natural resources, being the condition of life and an unsubstitutable component of the environment. In connection with a climatic change and methods of management, time and spatial uniformity of its occurrence (which is very affected by the landscape retention capacity) it becomes a considerable problem. Fig. 1 shows the schematic distribution of the total natural retention od catchment basin on the individual components The significance of the landscape retention capacity consists in balancing runoff conditions and reducing dangerous culmination discharges causing otherwise disastrous impacts on population and the landscape (Palát et al. 2010, Mašíček et al. 2011, Prax et al. 2010).

From the point of view of the landscape retention capacity the organization of land resources and using the landscape play an important role at storm rainfalls unlike long-term precipitation.

The occurrence of storm floods caused by rainfalls of very high intensity, short term duration and limited extent show evidence of the urgency of changes in the structure, use and the landscape arrangement resulting in the support of infiltration and thus increasing the soil retention capacity. For example, Dostál et al. (1997) and Kulhavý, Kováŕ (2000) dealt with changes in the land resources organization and using the landscape affecting hydrological and watermanagement conditions within partial drainage areas. 
The subject of our research was to evaluate statistically the effects of physical-geographical factors on the retention of water and runoff conditions in parts of the Opava catchment area. Statistical analyses were preceded by the assessment of hydrological conditions of the studied drainage area at the design storm rainfall depending on the actual condition of the landscape cover.

This work is based on the data about precipitations and runoff for 16 particular basins of the Opava river. The data were given to the Research institute of melioration and soil conservation Prague (VÚMOP) by the Czech meteorological institute Praha (ČHMÚ) within the framework of government project "Evaluation of flood situation in July 1997" (Hladný 1998).

\section{Material and methods}

Preparation and analyses of source data necessary to express the drainage basin characteristics from the aspect of retention and runoff conditions were carried out in the UNISTAT system. As for hydrological characteristics, potential retention, the flood wave volume, concentration time and culmination discharge were monitored. The significance of particular physicalgeographical factors affecting the retention of water and runoff conditions in particular parts of the Opava drainage basin was quantified by the statistical method of multiple regression and correlation analysis.

To determine hydrological characteristics of particular parts of the Opava drainage basin and the subsequent statistical evaluation it was necessary to describe the present condition of the landscape cover, topography, to determine the proportion of hydrological groups of soils in the drainage basin.

To evaluate the significance of physical and geographical factors showing the highest effect on the retention of water and runoff conditions in particular parts of the Opava drainage basin modelled on the design storm rainfall a statistical method was used of the multiple regression and correlation analysis. Calculations were carried out using the UNISTAT calculation system. As dependent variables entered the statistical program, i.e. the drainage basin potential retention, the volume of direct runoff from $1 \mathrm{~km}^{2}$, the time of concentration and specific discharge. As for independent variables (physical-geographical factors) affecting dependent variables the significance was assessed of geometrical and geomorphological factors (the thalweg length, the thalweg average inclination, slope area, the slope average inclination), soil characteristics and the landscape cover, the relative area proportion of arable land and permanent grassland, forests, town residential area (Dumbrovský 1998; Chow Ven Te 1964; Mašíček 2010; Patera

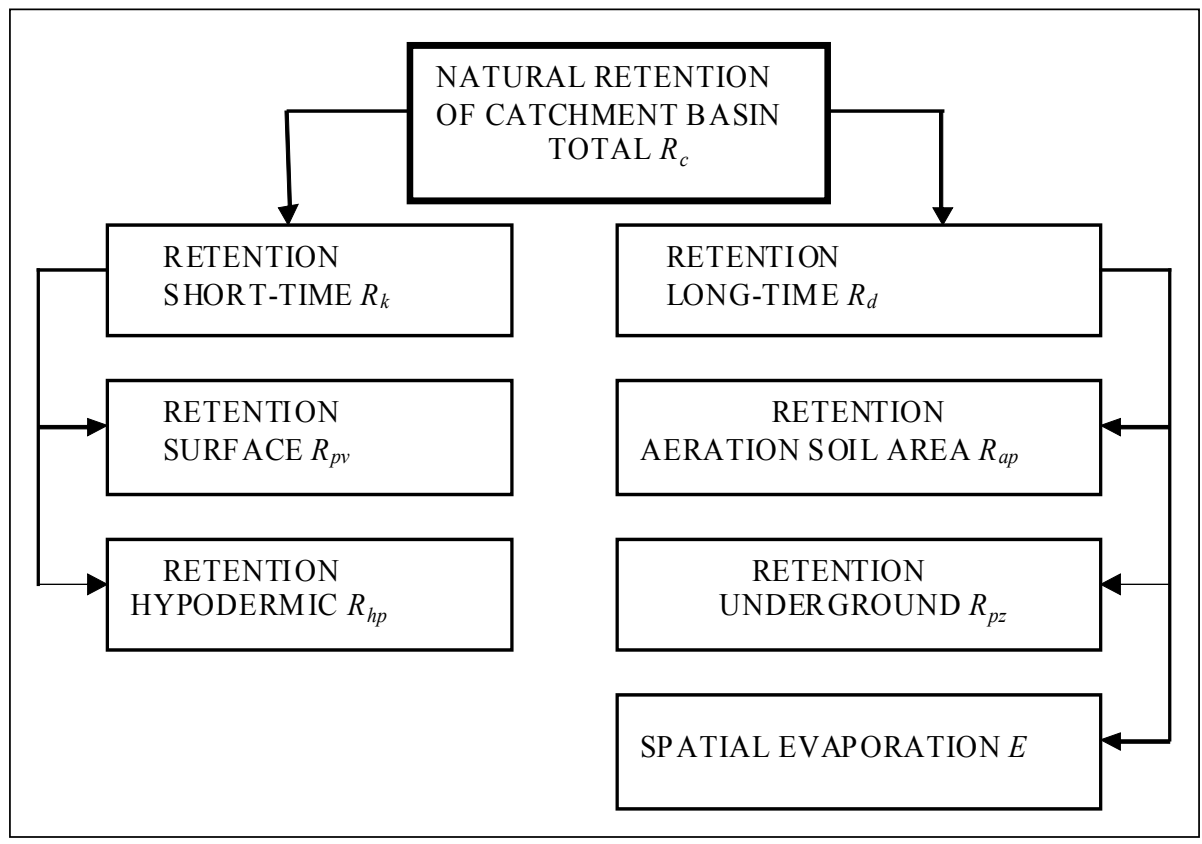

Fig. 1: Schematic distribution of the total natural retention of catchment basin $R_{c}$ on the individual components. 
2002; Prudký 2002, 2003; Prudký, Palát 2006; Spitz et al. 2000; Spitz, Prudký 2001; Trnka 2004, 2007).

For the selection of independent variables factors important for the quantitative determination of each of the dependent variables mentioned above, the method of step analysis by forward selection was used. The method makes it possible to select independent variables by successive steps from the most significant to the least significant ones. In the final stage, a certain number of independent variables affecting most the size of a respective dependent variable was selected though the step linear regression together with quantification of their effect through regression coefficients.

The significance of the selection was assessed on the basis of the correlation index $I$. The regression coefficient value of the respective independent variable expresses a change of the dependent variable by this value in case of a change of the respective independent variable by one unit. The closer to one the higher dependence (Mašíček, 2010). For the statistical evaluation of hydrological conditions methods described in papers of Palát et al. (2008), Seger et al. (1998), Palát (1991, 1997) and Palát et al. (2010) were used.

Basic concepts of the process of natural water retention are:

Total natural water retention of catchment basin $R_{c}$ is water temporarily delayed on the terrain surface, in the soil, in the stream bed, etc. in a natural way, i.e. without retention in artificial water reservoirs and in inundations. It can be further divided into five sub-components:

- surface retention $R_{p v}$, containing water delaying on the surface and in the stream bed,

- hypodermic retention $R_{h p}$, containing subsurface water moving in the immediate layer below the surface without reaching the water table,

- retention in the aeration soil area $R_{a p}$, consisting of water trapped in the capillaries of the unsaturated soil area and water infiltrating into the groundwater,

- underground retention $R_{p z}$, consisting of infiltration water increasing of groundwater supplies,

- spatial evaporation E, i.e. evaporation from the soil surface area with transpiration (evaporation by the plants) and interception (evaporation of the precipitation that sticks to the surface of the plant).

\section{Results and discussion}

Basic data of 16 sub-basins of the river Opava selected for statistical analysis is given in Tab. 2 . They are all river basins in the closing profiles as they were measured during the flood in 1997 by hydrometric stations of the Czech Hydrometeorological Institute.

For effective long-time retention for single catchment basin $R_{d e f}[\mathrm{~mm}]$ a following relation was derived:

$$
\begin{aligned}
R_{d e f}= & -464.7+0.1066 \Sigma H_{i}^{\prime}+4.79 F_{O P}^{\prime}+7.30 F_{T T P}^{\prime}+ \\
& +5.54 F_{L}^{\prime}-1.117 s_{t} \quad[\mathrm{~mm}](1)
\end{aligned}
$$

where: $\Sigma H^{\prime}$ - average depth of flood precipitation in catchment basin [mm], $F^{\prime}{ }_{O P}$ - relative area proportion of arable land [\% area of the basin],

$F_{\text {TTP }}^{\prime}$ - relative area proportion of permanent grasslands [\% area of the basin],

$F_{L}^{\prime}$-relative area proportion of forests [\% area of the basin],

$s_{t}$ - average terrain slope [angular degrees].

In this relation (1) more or less the expected characteristics (independent variables) are represented such as surface proportion of forest, grassland and field crops, the average slope of the terrain and of course the average depth of the flood precipitation in the catchment basin. If we make a step back in stepwise regression and reduce the value of F-value to 0.25 or 0.30 , other characteristics enter into the relation such as catchment area $\mathrm{F}$ in $\mathrm{km}^{2}$, stream length $\mathrm{L}$ in $\mathrm{km}$, coefficient of catchment basin shape $\omega$, and percentage of other areas (paved areas from hydrological point of view) with infamous rapid drainage. Due to the area occupied in the basin (often 3-5\%) they are not negligible. An interesting characteristic (though not unexpected) is the coefficient of previous precipitation API (Kulhavý, Kováŕ 2000).

For effective short-time retention of catchment basin $R_{k e f}^{\prime}[\mathrm{mm}]$ the following initially relation was derived:

$$
\begin{aligned}
R_{k e f}= & 309.204+1.11 H_{\max }^{\prime}-2.36 F_{O P}^{\prime}-4.48 F_{T T P}^{\prime}{ }^{-} \\
& -2.40 F_{L}^{\prime}-8.33 s_{t}
\end{aligned}
$$

where: $H^{\prime}{ }_{\max }$ - average maximum depth of flood daily precipitation in catchment basin $\left[\mathrm{mm} \cdot\right.$ day $\left.^{-1}\right]$,

$F^{\prime}{ }_{O P}, F_{T T P}^{\prime}, F_{L}^{\prime}$ a $s_{t}$ see relation (1)

Again, in step backward in step linear regression and setting the F-value to 0.9 or 1.0 we gain a further 8 characteristics, where in addition to recurring $\mathrm{H}_{\text {max }}^{\prime}, F_{\text {TTP }}^{\prime} F_{L}^{\prime}$ as $s_{t}$ and we can see a further characteristic of surface drainage percent of 
the basin area $\mathrm{F}^{\prime} \mathrm{O}$, then the length of the stream L in $\mathrm{km}$, index of previous precipitation API and shape coefficient of catchment basin $\omega$. Compared to the relationship remained unclassified arable land expressed as a percent of the basin area $\mathrm{F}_{\mathrm{OP}}^{\prime}$

Since the total size of the effective natural retention of catchment basin $R_{c e f}$ expressed in $\mathrm{mm}$ is the sum of effective long-term and short-term retention of catchment basin it can be determined by the sum of equations ( 1 ) and (2) modified in the expression:

$$
\begin{aligned}
R_{\text {cef }}= & -155.496+0.1066 \Sigma H_{i}^{\prime}+1.11 H^{\prime}{ }_{\text {max }}+ \\
& +2.43 F_{O P}^{\prime}+2.82 F_{T T P}^{\prime}+3.14 F_{L}^{\prime}{ }^{\prime}-9.447 s_{t}
\end{aligned}
$$

[mm] (3)

where: $H_{i}^{\prime}, F_{O P}^{\prime}, F_{T T P}^{\prime}, F_{L}, s_{t}$ see relation $(1)$,

$H^{\prime}{ }_{\max }$, see relation (2).
Again it is clear that for the wider relationship, as described above, it would be needful to include into both relationships the further already investigated and mentioned characteristics. It is not the aim of this work to treat the creation of new, expanded relationships even if it was not impossible and the authors of this post have them at their disposal. However, they consider that the disclosure of these enhanced relations will only make this work crowded. It will only be done for the maximum specific runoff from the catchment area $q_{\max }$ as an example.

Maximum specific runoff from the catchment basin $q_{\max }$ in $1 \cdot \mathrm{s}^{-1} \cdot \mathrm{km}^{-2}$ is determined by the relation:

where: $H^{\prime}{ }_{\text {max }}$, see relation (2),

$F_{\text {TTP }}^{\prime}, F_{\text {OP }}^{\prime}, F_{L}^{\prime}, s_{t}$ see relation (1).

\begin{tabular}{|c|c|c|c|}
\hline Independent variables & $\begin{array}{l}\text { Effective long-time } \\
\text { retention for single } \\
\text { catchment basin } \\
\boldsymbol{R}_{d e f}\end{array}$ & $\begin{array}{l}\text { Effective short-time } \\
\text { retention for single } \\
\text { catchment basin } \\
\boldsymbol{R}_{k e f}\end{array}$ & $\begin{array}{c}\text { Maximum specific } \\
\text { runoff } \\
\text { for single } \\
\text { catchment basin } \\
q_{\max }\end{array}$ \\
\hline Coefficient of catchment basin shape $\omega$ & NO & NO & YES \\
\hline Catchment basin area & YES & YES & YES \\
\hline Stream length L & YES & YES & YES \\
\hline Flood precipitation height & YES & YES & YES \\
\hline $\begin{array}{l}\text { Coefficient of previous precipitation } \\
\text { API }\end{array}$ & YES & YES & YES \\
\hline $\begin{array}{l}\text { Effective long-time retention of } \\
\text { catchment basin }\end{array}$ & $\mathrm{NO}$ & NO & YES \\
\hline $\begin{array}{l}\text { Effective short-time retention of } \\
\text { catchment basin }\end{array}$ & NO & NO & YES \\
\hline Maximum depth of daily precipitation & YES & YES & YES \\
\hline $\begin{array}{l}\text { Proportion of arable land in catchment } \\
\text { basin }\end{array}$ & YES & YES & YES \\
\hline $\begin{array}{l}\text { Proportion of permanent grasslands in } \\
\text { catchment basin }\end{array}$ & YES & YES & YES \\
\hline $\begin{array}{l}\text { Proportion of the other types of land in } \\
\text { catchment basin }\end{array}$ & YES & YES & YES \\
\hline $\begin{array}{l}\text { Proportion of hydrological group of } \\
\text { soils B }\end{array}$ & YES & YES & YES \\
\hline $\begin{array}{l}\text { Proportion of forests in catchment } \\
\text { basin }\end{array}$ & YES & YES & YES \\
\hline $\begin{array}{l}\text { Average terrain slope in catchment } \\
\text { basin }\end{array}$ & YES & YES & YES \\
\hline $\begin{array}{l}\text { Proportion of drainage in catchment } \\
\text { basin }\end{array}$ & YES & YES & YES \\
\hline
\end{tabular}

Tab. 1: Overview of the dependent and independent variables entering the statistical analysis 
Even this relationship can be imagined in a rather widespread form of a step backwards in step linear regression analysis. Determining the F-value 1.8 to 1.5, compared with the original ones, other terms appears such as the catchment area $\mathrm{F}$ in $\mathrm{km}^{2}$, then $\mathrm{F}^{\prime}$ osp the percentage of other areas in the basin, coefficient of previous precipitation API, proportion of hydrological group of soils B and the proportion of drainage in catchment basin.

Maximum specific runoff from the catchment basin $q_{\max } \mathrm{v} \cdot \mathrm{s}^{-1} \cdot \mathrm{km}^{-2}$ in extended form with seven independent variables determined by the relation:

$$
\begin{aligned}
\mathrm{Q}_{\max }= & 1221+8.86 F_{\text {OSP }}-47.64 \mathrm{~F}_{\mathrm{TTP}}-0.331 F+ \\
& +2.35 A P I+1.636 \Sigma H_{t}^{\prime}+35.44 s_{t}-36.25 B
\end{aligned}
$$

The above mentioned equations were derived for the floods of summer extreme long-standing regional rainfalls in the Opava catchment basin. The equation is valid for the following ranges of values independent variables: average amount of flood precipitation $\Sigma H^{\prime}$ from $167.6 \mathrm{~mm}$ to $686.0 \mathrm{~mm}$, maximum daily precipitation $H_{\max }$ from $46.7 \mathrm{~mm}$ to $198.8 \mathrm{~mm}$, proportion of the area of arable land in catchment basin $F^{\prime}{ }_{O P}$ from $0 \%$ to $53.51 \%$, permanent grasslands $F^{\prime}{ }_{T T P}$ from $0.81 \%$ to $26.55 \%$ and forests $F_{L}^{\prime}$ from $23.38 \%$ to
$98.07 \%$, the average terrain slope from $4.9^{\circ}$ to $11.3^{\circ}$ (Prudký 2003).

\section{Conclusion}

Based on the evaluation of the statistical analysis of floods caused by extreme regional rainfall in July 1997 in Opava River basin it is possible to draw conclusions on the significance of the various factors affecting the size of the retention capacity of the landscape. These factors can be simultaneously viewed as the hydrological characteristics of the catchment or landscape. For a broader generalization of these results a larger set of observations should be statistically evaluated.

Results of statistical analysis can be summarized in the following findings:

a) The magnitude of the effective retentions of catchment basin $R_{d e f}, R_{k e f}, R_{c e f}$ and maximum specific runoff from the catchment basin $q_{\max }$ most affects either the average depth of flood precipitation in catchment basin $\Sigma$ H'i, (for variables $R_{d e f}, R_{c e}$ ) or the average maximum depth of the flood daily rainfall in the catchment $\mathrm{H}$ 'max (for variables $R_{k e f}, R_{c e f}, q_{\text {max }}$ ).

b) Higher relative area proportion of arable land $\boldsymbol{F}_{\boldsymbol{O P}}{ }_{\boldsymbol{P}}$ increases the effective long-term retention of the catchment basin $R_{d e f}$ and

Tab. 2: Basic data on the Opava river sub-basins selected for statistical analysis

\begin{tabular}{cccccc}
\hline $\begin{array}{c}\text { Catchment } \\
\text { basin serial } \\
\text { number }\end{array}$ & $\begin{array}{c}\text { Data bank } \\
\text { number }\end{array}$ & $\begin{array}{c}\text { Name of hydrometric station } \\
\text { in the conclusion profile of } \\
\text { catchment basin }\end{array}$ & Stream name & $\begin{array}{c}\text { Number of } \\
\text { hydrological } \\
\text { catchment basin }\end{array}$ & $\begin{array}{c}\text { Catchment } \\
\text { basin area } \\
{\left[\mathbf{k m}^{2} \text { ] }\right.}\end{array}$ \\
\hline 1. & 2851 & Mnichov & Černá Opava & $2-02-01-003$ & 51.46 \\
2. & 2590 & Železná & Střední Opava & $2-02-01-008$ & 54.28 \\
3. & 2612 & Karlovice & Opava & $2-02-01-011$ & 151.29 \\
4. & 2630 & Krnov & Opava & $2-02-01-037$ & 370.50 \\
5. & 2650 & Krnov & Opavice & $2-02-01-056$ & 175.98 \\
6. & 2660 & Opava & Opava & $2-02-01-089$ & 929.65 \\
7. & 2680 & Malá Morávka & Bělokamenný potok & $2-02-02-006$ & 16.50 \\
8. & 2690 & Rýmařov & Podolskýpotok & $2-02-02-016$ & 50.67 \\
9. & 2700 & Velká Štáhle & Moravice & $2-02-02-021$ & 168.06 \\
10. & 2701 & Valšov & Moravice & $2-02-02-027$ & 243.28 \\
11. & 2711 & Mezina & Černýpotok & $2-02-02-048$ & 92.16 \\
12. & 2723 & Slezká Harta pod nádrží & Moravice & $2-02-02-055$ & 464.31 \\
13. & 2730 & Kružberk pod nádrží & Moravice & $2-02-02-065$ & 566.67 \\
14. & 2740 & Branka & Moravice & $2-02-02-077$ & 716.33 \\
15. & 2741 & Jakartovice & Hvozdnice & $2-02-02-080$ & 31.08 \\
16. & 2750 & Děhylov & Opava & $2-02-03-023$ & 2039.11 \\
\hline & & & & &
\end{tabular}


reduces the maximum specific runoff from the catchment basin.

c) Higher relative area proportion of permanent grasslands in the catchment basin $F^{\prime}{ }_{\text {TTP }}$ increases the effective long-term retention of catchment basin $R_{\text {def }}$ and reduces the maximum specific runoff from the catchment basin $q_{\max }$.

d) Higher relative area proportion of forests $F_{L}^{\prime}$ increases the effective long-term retention of catchment basin $R_{d e f}$, and reduces the maximum specific runoff from catchment basin $q_{\text {max }}$

e) With a higher average terrain slope of catchment basin $s_{t}$ the effective long-term retention catchment basin $R_{\text {def }}$ adversely reduces, the maximum specific runoff from the catchment basin $q_{\text {mx }}$ adversely increases and the effective short-time retention of catchment basin $R_{k e f}$ reduces.

f) Higher index value of the previous precipitation API adversely reduces the effective long-time retention $R_{d e f}$ and adversely increases the maximum specific runoff from the catchment basin $q_{\max }$.

g) With a higher relative abundance of other surfaces (hard surfaces) the maximum specific runoff for catchment basin $q_{\max }$ increases and the effective long-term retention $R_{\text {def }}$ reduces.

h) With a higher proportion of hydrological group of soils B (percolation 0.06 to 0.12 $\mathrm{mm} / \mathrm{min}$ ) the effective long-time retention increases and the maximum specific runoff from catchment basin $q_{\max }$ reduces.

i) A higher value of effective long-time retention for catchment basin $R_{\text {def }}$, reduces the maximum specific runoff from the catchment basin $q_{\max }$.

j) Effective long-time retention of catchment basin $R_{d e}$, that expresses what proportion of torrential or regional rain is the catchment basin harmlessly able to delay and distract (i.e. what proportion is trapped in the soil and evaporates) has a positive effect on reduction of flood flow as well as on harmful overflowing. However, in landslide areas it may cause landslides.

k) The influence of effective short-time retention of catchment basin $R_{k e f}$, containing water delays on the ground, in the bed of the stream and hypodermic water is not unambiguous for positive transformation floods. During large floods it is usually a harmful component of overall retention, as it may cause harmful water overflow. For smaller floods, however, it can help to reduce flood discharge.

l) The significance of individual factors expressing the hydrological characteristics of the catchment basin referred to in points from a) to e) can be judged by the size of their coefficients in the regression equations.

m) The positive effect of arable land emerged from the state of all crops in the first half of July 1997, when particularly root system of cereals and fodder had already been developed enough to support the infiltration of water.

It is also necessary to mention briefly the quantitative process of natural water retention of the catchment basin, as it has great practical significance. Due to a certain ambiguity effect of effective short-time retention of catchment basin $R_{k e f}$, (see point $h$ ), the effective long-time retention $R_{d e f}$ for monitoring the effects of retention was selected. The coefficient of effective long-time retention $\rho_{\text {def }}$ is the ratio between the value of effective long-time retention and flood volume of precipitation.

Values $\rho_{\text {def }}$ vary for different sub-basins as follows: 0.22 for the river Moravice under Kružbersk reservoir, 0.23 for the river Opava at Karlovice and in Krnov, 0.24 for Bělokamenný stream in the Morávka, 0.25 for Černá Opava in Mnichov and Opava, Opava, 0.26 for Opavice in Krnov 0.27 for Moravice profile Slezská Harta under the reservoir and Střední Opava in Železné, 0.28 for Černý potok in Mezina, 0.32 for Opava in Děhylov, 0.35 for Moravice in Velká Štáhle, 0.36 for Moravice in Valšov, 0.37 for Hvozdnice in Jakartovice and 0.48 for Podolský potok in Rýmařov.

Long-time effective retention, expressed in millimeters, has the following values in the same order: $67.7,143.5,10.9,85.9,169.5,100.1$, 78.8, 120.2, 83.7, 130 , 1, 83.6, 78.7, 129.9, 127.1, 62.6 and 134.9 .

\section{Acknowledgements}

The paper was supported by the GAČR 103/07/0676. 


\section{References}

Dumbrovský, M. 1998: Rozbor retenčního potenciálu povodí reky Opavy s analýzou zastoupení a plošného rozmisténi kultur (zpráva). [Analysis of potential retention of the Opava river drainage basin with analysis of representation and cultures layout (report)]. VÚMOP Praha, 25 pp.

DostáL, T., KuRÁž, V., VÁšKA, J., VRÁNA, K. 1997: Využití povodía jeho vliv na režim povrchového odtoku [The use of a drainage basin and its effect on the surface runoff régime]. In: Povodnéa krajina '97. Sborník posteru. ICIDCIID, Brno.

HladnÝ, J. 1998: Vyhodnocení povodñové situace $v$ červenci 1997. [Evaluation of the flood situation in July 1997]. Vládní projekt.

Chow Ven Te 1964: Handbook of Applied Hydrology. Mc Graw - Hill Book Company New York, 1467 pp.

KulhavÝ, Z., Kovář, P. 2000: Využití modeli hydrologické bilance pro malá povodí [The use of hydrological balance models for small drainage basins]. VÚMOP, Praha, 123 pp.

MAŠÍČEK, T. 2010: Stanovení potenciální retence povodí řeky Fryšávky [Determination of the potential retention of the Fryšávka river drainage basin]. Acta Universitatis Agriculturae et Silviculturae Mendelianae Brunensis. Vol. LVIII, 5: 263-270.

Mašíček, T., Toman, F., Palát, M. 201l: Using the Step Linear Regression at the Analysis of Hydrological Conditions of the Fryšávka Drainage Basin. Infrastruktura and Ecology of Rural Areas, 11: 71-86.

PALÁt, M. 1991: Model of the organic matter flow in a representative of the foodplain forest. In: Penka, M., Vyskot, M., Klimo, E., VAŠÍČEK, F. (eds.): Floodplain forest Ecosystem. 2. After Water Management Measures, Academia Praha/Elsevir Amsterdam, 265-277.

PalÁt, M. 1997: Biomass flow in a floodplain forest ecosystem and in man-made Norway spruce forest. Forestry, 43 (10): 441-452.

Palát, M., Prax, A., Palát, M., Rožnovský, J. 2010: Causes and consequences of a flood wave on the lower reach of the Dyje River near Břeclav. Soil and Water Research, 5 (4): 121-127.

Palát, M., Prudký, J., Palát, M. 2008: Vnitřní dynamika procesu krokové lineární regrese užité při analýze přirozené retence vody v povodí řeky Opavy za povodně v červenci 1997 [Inner dynamics of the process of step linear regression used at the analysis of the natural retention of water in the Opava river drainage basin during a flood in July 1997]. In: FLAK, P. (ed.): Biometric methods and models of agricultural science, research and teaching. XVIII. Summer school of biometrics, Račkova dolina. 1st ed., Publishing of Slovak University of Agriculture in Nitra, Nitra, 121-129.

Patera, A. 2002: Povodné: prognózy, vodní toky a krajina [Floods: forecasts, watercourses and the landscape]. ČVÚT v Praze, Praha, 436 pp.

Prax, P., Rožnovský, J., Palát, M. 2010: Měrené, validace a analýza dlouhodobých deštových rad $v$ méstském odvodnèní [Measurement, validation and long time rain series analysis in urban hydrology]. 1. vyd. Brno: VUTIUM Brno, 108 pp.

PrudKŕ, J. 2002: Analýza přirozené retence vody $\mathrm{v}$ povodí řeky Opavy při povodni v červenci 1997 [Analysis of the natural retention of water in the Opava river drainage basin at a flood in July 1997]. Soil and Water, 1: 89-101.

PrudKý, J. 2003: Analýza přirozené retence vody v povodí řeky Opavy při povodni $\mathrm{v}$ červenci 1997[Analysis of the natural retention of water in the Opava river drainage basin at a flood in July 1997]. Acta Hydrologica Slovaca, 4 (2): 248-254.

PrudKý, J. PAlát, M. 2006: Vnitřní dynamika procesu krokové lineární regrese užité při analýze přirozené retence vody $\mathrm{v}$ povodí řeky Opavy za povodně v červenci 1997 [Inner dynamics of the process of step linear regression used at the analysis of the natural retention of water in the Opava river drainage basin during a flood in July 1997]. Bioklimatológia a voda v krajině. Bratislava: FMFI, Comenius university, Bratislava, 1-9.

Seger, J., Hindls R., Hronová, S. 1998: Statistika $v$ hospodárství [Statistics in the economy], ECT Publishing Praha, 636 pp.

Spitz, P., Dumbrovský, M., PodhrázskÁ, J. 2000: Hodnocení retenční schopnosti krajiny při povodni [Evaluation of retention capacity of landscape during the flood]. Védecké práce VÚMOP Praha, 11: 137-147.

SpItz, P., PrudKŕ, J. 2001: Metodika výpočtu retence povodí pri povodních (zpráva) [Methodology for calculating basin retention during the flood (report)]. Uživatelský výstup projektu NAZV č. EP 9153 „Hodnocení vodní retenční kapacity půd a krajiny při povodni a možnosti jejího zvyšování“, VÚMOP Praha, 19 pp. 
TRNKA, P. 2004: Landscape microstructures and their fate in the central part of the Bohemian-Moravian Upland. Moravian Geographical Reports, Brno, 12: 46-56.

TRnkA P. 2007: Krajina v povodí Fryšávky se predstavuje. Krajina a její promèny $v$ zrcadle času [Landscape in the Fryšávka drainage basin introduces itself. The Fryšávka landscape and its metamorphoses in the mirror of time]. Žd'ár nad Sázavou: ERC workgroup Prameny Vysočiny, o. p. s., 15 pp. 